\title{
Analisis Pemikiran Teologi Islam Rasional Sutan Takdir Alisjahbana Menuju Peradaban Modern
}

\author{
Atika Yulanda \\ Mahasiswi Pascasarjana UIN Sunan Kalijaga Yogyakarta \\ atikayulanda24@gmail.com
}

\begin{abstract}
Humans as religious creatures will always hold their belief in One God. The belief in God is embedded in theological issues. Theology here is a theme related to divine issues, God's relationship with humans, nature and His attributes. Humans are gifted by Allah in the form of reason by which they are able to judge and cultivate what is good and what is right. In addition, with the potential of their intellect, they are also able to prove the existence of God's power and the existence of God in human life. Intellect here does not position it as the highest but is in line with revelation as the source of Islamic teachings. This theology is called rational theology. In rational theology the positions of reason and revelation are parallel. Reason as confirmation and revelation as information. An Indonesian cultural figure who puts his thoughts related to theology, namely Sutan Takedir Alisjabbana. He is of the view that bumans with the potential of their intellect are able to compete with the outside world and are able to keep up with the times. However, it is not justified to abandon the values contained in the Qur'an and Hadith. This rational theology of Sutan Takdir Alisjabbana assesses reason as being able to keep up with the times and so that Muslims do not experience setbacks. The setbacks that are happening now are due to those who do not want to be open to the Western world which has been advanced and is only static. Meanwhile, in the teachings of Islam, humans are required to use the potential of reason that has been granted by Allah SWT. This rational Islamic theology is very important for the development of Islam today because there are still human thoughts that are still static and closed to knowledge that comes from outside.
\end{abstract}

Keyword: Theology, Sutan Takdir Alisjahbana, Rasional Theology

Abstrak. Manusia sebagai makhluk yang beragama akan selalu memegang keyakinannya kepada Tuhan yang Esa. Keyakinan akan adanya Tuhan tercantum dalam permasalahan teologi. Teologi di sini sebagai tema yang berkaitan dengan permasalahan ketuhanan, hubungan Tuhan dengan manusia, alam dan sifat-sifatNya. Manusia dianugerahi oleh Allah berupa akal yang dengan itu mereka mampu untuk menilai dan mengolah mana yang baik dan mana yang benar. Selain itu, dengan potensi akal mereka juga mampu membuktikan akan adanya kekuasaan Tuhan dan adanya Tuhan dalam kehidupan manusia. Akal disini tidak memposisikannya sebagai yang tertinggi namun beriringan dengan wahyu sebagai sumber ajaran Islam. Teologi ini dinamakan dengan teologi rasional. Dalam teologi rasional posisi akal dan wahyu sejajar. Akal sebagai konfirmasi dan wahyu sebagai informasi. Seorang tokoh kebudayaan Indonesia yang menyampaikan pemikirannya terkait dengan teologi yaitu Sutan Takdir Alisjahbana. Ia berpandangan bahwa manusia dengan potensi akal yang dimiliki mampu bersaing dengan dunia luar dan mampu untuk mengikuti perkembangan zaman. Namun tidak dibenarkan untuk 
meninggalkan nilai-nilai yang terkandung di dalam al-Qur'an dan Hadis. Teologi rasional dari Sutan Takdir Alisjahbana ini manila akal mampu untuk mengikuti perkembangan zaman dan agar umat Islam tidak mengalami kemunduran. Kemunduran yang terjadi sekarang ini dikarenakan mereka yang tidak mau terbuka akan dunia Barat yang telah maju dan hanya bersifat statis. Sedangkan dalam ajaran Islam manusia dituntut untuk menggunakan potensi akal yang telah dianugerahi oleh Allah SWT. Teologi Islam rasional ini sangat penting untuk perkembangan Islam sekarang ini karena masih ada pemikiran manusia yang masih bersifat statis dan tertutup terhadap pengetahuan yang datang dari luar.

Kata Kunci: Teologi, Sutan Takdir Alisjahbana, Teologi Rasional.

\section{PENDAHULUAN}

Teologi merupakan salah satu permasalahan yang ada dalam ajaran Islam. Adanya teologi Islam rasional dan teologi Islam Tradisional. Kedua teologi ini masih menggunakan serta menyeimbangkan antara satu dengan yang lain. Contohnya terkait akal dan wahyu, dalam pemikiran teologi tradisional wahyu al-Qur'an dan Hadis sebagai informasi dan akal sebagai konfirmasi. Antara keduanya tidak ada yang tinggi namun saling melengkapi. Begitu juga dengan teologi rasional, menempatkan akal sebagai informasi dan wahyu sebagai konfirmasi. Apa yang ditanggapi oleh akal akan dikonfirmasikan atau disesuaikan dengan wahyu yaitu al-Qur'an dan Sunnah. Jika tidak sesuai dengan ajaran Islam al-Qur'an dan Hadis maka tidak akan digunakan. Disini dapat dipahami bahwa antara teologi tradisional dan rasional sama-sama saling membutuhkan dan tidak ada pertentangan antara satu dengan yang lain (Mangunhardjana, 1997, h. 222).

Dalam permasalahan teologi banyak membicarakan terkait dengan peristiwa mengkafirkan. Dalam aliran tradisional, sumber ajaran Islam hanya wahyu dan barang siapa yang menggunakan akal maka akan dinilai kafir. Ilmu pengetahuan yang datang dari Barat dinilai membawa kekafiran dan menjauhkan dari nilai-nilai keislaman. Sedangkan aliran rasional, akal dinilai mampu untuk mengetahui kewajiban-kewajiban manusia namun dikonfirmasikan dengan wahyu yaitu al-Qur'an dan Hadis. Aliran tradisional dapat dilihat pada aliran Asy'ariyah sedangkan rasional seperti Mu'tazilah.

Salah satu tokoh teologi Islam yang memusatkan pemikirannya kepada teologi khususnya teologi rasional yaitu Sutan Takdir Alisjahbana. Ia adalah seorang budayawan, sastrawan Indonesia. Sutan Takdir Alisjahbana melihat kondisi kebudayaan di Indonesia yang tidak mau bahkan memvonis kebudayaan yang datang dari Barat akan membawa kepada kekufuran. Padahal sebagaimana yang diketahui, Indonesia mayoritas penduduknya beragama Islam dan umat Nabi Muhammad SAW. Nabi Muhammad 
memiliki sifat yang cerdas dan menggunakan akal pikirannya untuk mengatasi permasalahan. Ia tidak melarang umatnya untuk berijtihad asalkan tidak keluar dari ajaran al-Qur'an dan Sunnah. Namun yang ditemukan sekarang ini yaitu kebanyakan orang Indonesia masih menganggap kebudayaan dan ilmu pengetahuan yang datang dari Barat bersifat negatif dan membawa kepada kekafiran. Oleh karena itu, Sutan Takdir Alisjahbana menolak hal tersebut dan menganggap mereka telah salah dalam memandang suatu kebudayaan. Ia berpandangan jika masih memiliki pemikiran seperti itu maka akan tetap menjadi umat yang terbelakang. Sedangkan manusia menurutnya telah dianugerahi oleh Allah akal pikiran untuk memilih dan memilah mana yang baik dan mana yang buruk. Selain itu, dituntut untuk menggunakan potensi akal yang ada.

Oleh karena itu, penulis tertarik untuk mengkaji lebih dalam terkait dengan pemikiran teologi Islam dan Rasional dari Sutan Takdir Alisjahbana. Bagaimana seorang budayawan, sastrawan sekaligus ahli bahasa dalam mencurahkan pandangannya terhadap kondisi dan situasi yang demikian. Maka dalam makalah ini akan dibahas lebih lanjut terkait Sutan Takdir Alisjahbana: Islamic Theology and Rationalism.

Jenis penelitian ini adalah library Research atau studi kepustakaan. Artinya, penelitian ini dilakukan melalui penelusuran dan telaah terhadap karya-karya ilmiah baik yang tertuang dalam buku, majalah, jurnal, makalah, serta berbagai media yang mengulas topik penelitian. Sumber data dalam penelitian ini meliputi dua hal, yaitu sumber primer dan sumber sekunder. Adapun sumber data primer yaitu sumber data yang langsung dikumpulkan peneliti dari sumber pertamanya. Dalam hal ini buku-buku karangan Sutan Takdir Alisjahbana. Adapun sumber sekunder yaitu karya-karya lain yang membahas tentang Sutan Takdir Alisjahbana terkait dengan Teologi Islam Rasional dan implikasinya dengan era modern serta karya-karya lainnya.

\section{HASIL DAN PEMBAHASAN}

\section{Biografi dan Kondisi Sosial Budaya Sutan Takdir Alisjahbana}

Sutan Takdir Alisjahbana merupakan seorang budayawan, sastrawan dan ahli bahasa Indonesia (Suseno, 1998, h. 7) ${ }^{1}$. Ia merupakan seorang tokoh

\footnotetext{
${ }^{1}$ Sebagai seorang ahli tata bahasa Indonesia, Sutan Takdir Alisjahbana dikenal sebagai penerjemah beberapa karya dari tokoh-tokoh besar filsafat dunia. Dalam pandangan Frans Magnis Suseno, ia menegaskan mereka untuk selalu membuat tulisan-tulisan para pemikir besar dunia serta diterjemahkan ke dalam bahasa Indonesia. Selain itu, beliau juga menyarankan kepada para pemikir selanjutnya untuk melihat serta mencontoh bagaimana
} 
yang sangat menaruhkan pemikirannya terhadap kebudayaan di Indonesia bahkan juga menaruh perhatian terhadap kebudayaan yang ada di Indonesia. Selain itu, ia juga seorang sastrawan terkenal yang dibuktikan dengan beragam jenisnya karya sastra yang dikarang oleh Sutan Takdir Alisjahbana. Sutan Takdir Alisjahbana yang merupakan tokoh asli dari Indonesia yaitu tepatnya di Natal, Tapanuli Selatan tepatnya di pantai Barat Sumatera pada 11 Februari 1908. Ia berasal dari keturunan Minangkabau dari pihak ibu dan dari keturunan ayah berdarah Jawa. Ayahnya Raden Alisjahbana adalah seorang sultan dan bekerja sebagai seorang guru di Bengkulu. Pemikiran Sutan Takdir Alisjahbana dipengaruhi oleh ayahnya (Suseno, 1998, h. 106).

Saat masih kecil, Sutan Takdir Alisjahbana bukanlah seorang kutu buku dan menghabiskan waktunya untuk belajar. Ia selalu bermain dengan teman sebaya dan tergolong anak yang suka bermain. Walaupun kakek dari Sutan sendiri terkenal alim ulama dan memiliki pengetahuan agama yang cukup luas. Walaupun ia berasal dari keluarga yang taat beragama, namun pribadinya sangat berbeda dari yang lain. Ia tidak tertarik dalam mendalami ilmu agama. Sebagaimana dalam sebuah perkataan Sutan Takdir Alisyahbana: (S. Takdir Alisyahbana, 1992, h. v)

"saya sendiri waktu kanak-kanak tidak tertarik akan agama. Kalau sore hari saya bersama-sama sepupu-sepuри saya disuruh pergi belajar mengaji, sering saya berhenti di jalan dan turun ke bawah jembatan untuk. menangkap udang, dan kalau sepupu saya pulang saya pulang bersama-sama mereka. Dengan demikian saya tidak pernah menamatkan Al-Quran.”

Selain itu, Sutan juga memiliki hubungan yang dekat dengan Sutan Syahrir yang kemudian juga turut mempengaruhi pemikiran Sutan Takdir Alisjahbana. Terkait dengan kehidupan keluarga, Sutan diketahui memiliki tiga orang istri, dari ketiga istri-istrinya itu dikaruniai 9 orang anak. Ketiga istrinya ini dinikahi setelah istri pertama dan istri keduanya meninggal dunia. Ia tidak pernah melakukan poligami terhadap ketiga istri ini. Setelah istri pertama meninggal, beberapa bulan setelah itu ia menikah dengan istri kedua.

Pada tahun 1921, Sutan Takdir Alisjahbana menempuh pendidikan untuk pertama kalinya di sekolah HIS Bengkulu. Tamat dari sana ia menempuh pendidikan ke HKS bandung pada tahun 1928. Selain itu, meraih gelar Mr. dari sekolah Tinggi di Jakarta pada tahun 1942 dan menerima Dr. Honoris Causa dari Universitas Indonesia dan Universitas

pemikir-pemikir Jepang yang dengan teliti dan gigih menerjemahkan karya-karya pemikir dunia ke dalam bahasa Jepang. 
Sains Malaysia pada tahun 1987. Ia merupakan seorang tokoh yang aktif serta sangat peduli terhadap kebudayaan di Indonesia. Ia sangat aktif dalam bidang sastra. Itu terlihat dari karya-karyanya antara lain Tak Putus dirundung Malang (Novel, 1929), Dian Tak Kunjung Padam (Novel, 1932), Tebaran Mega (Kumpulan sajak, 1935), Tatabahasa Baru Bahasa Indonesia (1936), Layar terkembang (Novel, 1936), Anak perawan di Sarang Penyamun (Novel, 1940), Puisi Lama (Bunga Rampai, 1941). Selain karya sastra di atas ia juga pernah menjadi seorang editor diantaranya Kreativitas (Kumpulan esai, 1984) dan Dasar-dasar Kritis semesta dan tanggung jawab kita (kumpulan esai, 1984) dan juga menjadi seorang penerjemah pada karya Pierre Loti yang berjudul Nelayan di Laut Utara tahun 1944 serta karya Tadayoshi Sakurai yang berjudul Nikudan Korban Manusia tabun 1944. Oleh karena inilah Sutan Takdir Alisjahbana disebut juga sebagai seorang ahli bahasa (Dian Nur Anna, 2018, h. 78)

Sebagai seorang budayawan dan sastrawan sekaligus ahli bahasa Indonesia, ia sangat mempunyai pengaruh terhadap perkembangan budaya di Indonesia. Ia juga terkenal sebagai seorang liberal yang anti dengan sikap statis. Menurutnya seseorang harus memiliki sikap kebebasan dan tidak boleh tunduk dengan suatu hal selagi masih sesuai dengan ajaran dan nilai-nilai agama. Sebagai tokoh Indonesia ia sangat prihatin dengan kondisi sosial dan kebudayaan Indonesia. Ia menganggap orang Indonesia yang mayoritas agama Islam masih memegang sikap statis dan tidak mampu melangkah ke arah yang lebih maju. Mereka takut jika mereka melakukan sesuatu hal akan membawa kepada keburukan dan jauh dari nilai agama. Sedangkan Allah telah memberikan manusia sesuatu yang berbeda dari makhluk Tuhan lainnya yaitu potensi akal pikiran. Dengan akal inilah mampu membedakan manusia dengan hewan dan tumbuhan serta makhluk Tuhan lainnya.

Sutan Takdir Alisjahbana prihatin dengan kondisi kebudayaan di Indonesia yang masih tradisional dan tidak mau terbuka dengan dunia luar. Sedangkan jika ingin maju dan mengikuti zaman harus adanya sikap dinamis dan terbuka dengan dunia luar. Mereka beranggapan jika melihat kepada dunia Barat akan membawa kepada kekafiran karena sebagian besar mereka tidaklah beragama Islam bahkan atheis. Sedangkan antara keduanya saling berhubungan (Amin Abdullah, 2007, h. 53). Menurut Sutan tidaklah benar, dengan adanya akal yang dianugerahi oleh Allah maka akan bisa digunakan untuk memilih dan memilah mana yang benar dan sesuai dengan ajaran Islam. 
Kebudayaan Indonesia asli di antaranya yaitu mereka sangat mempercayai segala bentuk mitos, hal-hal gaib dan lainnya yang bahkan itu semua telah mempengaruhi pemikiran mereka untuk bertindak statis, begitu kuatnya nilai-nilai agama dalam kehidupan mereka memungkinkan mereka untuk menutup diri terhadap dunia luar (S. Takdir Alisjahbana, 1977, h. 12). Sebagai contohnya tadi terhadap dunia Barat. Mereka menganggap jika melihat ke arah Barat atau Eropa akan membawa kepada kekufuran dan menjauhi dari nilai-nilai agama. Kondisi seperti ini yang menimbulkan Sutan Takdir Alisjahbana menuangkan pemikiran-pemikirannya terhadap kehidupan Indonesia. Menurutnya harus adanya pemikiran yang rasional dan harus adanya tindakan dinamis agar tidak jauh berbeda dengan Negaranegara maju seperti Eropa dan Negara Barat lainnya.

Semasa hidupnya Sutan Takdir Alisjahbana pernah menderita sakit jantung dan dirawat di rumah sakit Cimahi Bandung. Namun itu tidak menurunkan semangat Sutan untuk menulis karya-karya serta menjadi seorang guru. Sutan Takdir Alisjahbana meninggal pada tahun 1994 dan dikenal sebagai seorang budayawan Indonesia.

\section{Teologi Islam dan Rasional Sutan Takdir Alisjahbana}

Sutan Takdir Alisjahbana sebagaimana yang diketahui adalah seorang pemikir Indonesia yang liberal. Ia memiliki pandangan yang rasional terhadap apapun. Kerasionalan ini tidak bermaksud menghilangkan aspek-aspek religius dalam dirinya. Ia berpandangan bahwa potensi akal yang dianugerahi oleh Allah harus dimanfaatkan dengan baik. Akal menurutnya sebagai informasi sedangkan wahyu seperti al-Qur'an dan hadis sebagai konfirmasi. Konfirmasi disini maksudnya yaitu manusia dituntut untuk menggunakan akal dalam memahami sesuatu ataupun dalam menginterpretasikan sesuatu asalkan sesuai dengan ajaran Islam al-Qur'an dan wahyu. Jika yang ditangkap oleh akal tidak sesuai dengan ajaran Islam maka harus ditolak dan ditinggalkan. Pandangan ini sama dengan pemikiran Harun Nasution. Akal menurutnya sebagai informasi sedangkan wahyu sebagai konfirmasi (Nasution, 1986, h. 35). Menurutnya Allah telah memberikan manusia potensi akal dan dengan itu manusia mampu melakukan perbuatan dan mampu mempertanggungjawabkan serta tidak melampaui bahkan tidak menentang nilai-nilai agama. Jika hanya tunduk dan tidak mau berubah maka akan tetap statis dan tidak ada kemajuan dari dahulu sampai sekarang ini. Selain itu akan membawa kepada kehidupan yang terbelakang dan tidak maju. 
Humanisme (Bagus, 1996, h. 12) yang ada di Negara Eropa sejak Renaissance dan neo-Positivisme sangat mempengaruhi pemikiran Sutan Takdir Alisjahbana. Humanisme ini dibangun berdasarkan tiga narasi besar. Pertama, pembebasan manusia dari belenggu mitologi dan agama. Ini terlihat dari kebudayaan Indonesia yang masih kental dengan tradisi-tradisi mitos dan mempercayai yang gaib padahal itu semua akan membawa kepada sikap statis. Jika masih tetap mempercayai hal-hal demikian akan berdampak kepada tidak maunya berkembang ke arah yang baru. Menurut Sutan Takdir Alisjahbana manusia tidak harus tunduk dan pasrah terhadap sesuatu, harus adanya perubahan dan kerja keras untuk memperoleh perubahan menuju arah lebih baik.

Kedua, bertujuan spirit yang dijumpai dalam idealisme (Bagus, 1996, h. $300)^{2}$ Hegel dan kaum romantik seperti Fichte dan Schelling. Ketiga,

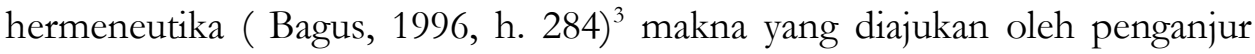
paham historisme seperti Wilhelm Dilthey. Semua itu melahirkan humanisme sekuler dan fundamentalisme rasional.

Teologi Islam sebagaimana yang diketahui merupakan suatu ilmu yang membahas tentang ushul sebagai suatu aqidah tentang keesaan Allah SWT, wujud dan sifat-Nya, Rasul-rasul-Nya, Kitab-kitab-Nya dan sebagainya yang diperkuat dengan dalil-dalil akal dan meyakinkan (Mansur, 1994, h. 23). Dalam teologi Islam juga membahas bagaimana kebebasan manusia dalam bertindak, kedudukan akal dan wahyu. Semua itu terdapat perbedaan antara yang rasional dan tradisional. Sutan Takdir Alisjahbana berpandangan rasional dan lebih menekankan kepada penggunaan akal dan dikonfimasikan dengan wahyu. Dalam al-Qur'an telah banyak ditemukan penegasan penggunaan akal dalam kehidupan manusia. Dalam melihat setiap

${ }^{2}$ Dalam bahasa Inggris idealism. Sebuah istilah yang pertama kali digunakan secara filosofis oleh Leibniz awal abad ke-18. Ia menerapkan istilah inipada pemikiran Plato, seraya memperlawankannya dengan materialism Epikuros. Beberapa tepri tentang pengertian idealism. 1. yaitu teori bahwa alam semesta adalah suatu penjelmaan pikiran. 2. untuk bereksistensi realitas tergantung pada suatu pikiran dan aktivitas-aktivitas pikiran. 3. seluruh realitas itu bersifat mental. Materi, yang fisik, tidak ada. 4. Tidak ada pengetahuan yang mungkin selain keadaan-keadaan dan proses-proses mental, da itu saja yang ada. 5. Realitas dijelaskan berkenaan dengan gejala-gejala psikis seperti pikiran-pikiran, diri, roh, ide-ide, pikiran mutlak dan seterusnya dan bukan berkenaan dengan materi.

${ }^{3}$ Dalam bahasa Inggris hermeneutic dan dari bahasa Yunani hermeneutikos (penafsiran). Hermeneutika merupakan ilmu dan teori tentang penafsiran yang bertujuan menjelaskan teks mulai dari ciri-cirinya baik objektif maupun subjektif. Dalam penggunaan klasik, istilah ini mengacu kepada penafsiranteks-teks khususnya teks-teks al-Kitab tetapi juga teks-teks filosofis. Dalam filsafat ilmu sosial terdapat pandangan bahwa metode ilmu-ilmu sosial lebih dekat dengan hermeneutika daripada ilmu-ilmu eksperimental. 
permasalahan dan penciptaan langit dan bumi manusia diberi potensi akal dan dengan itu mereka mampu melihat semua keajaiban dan penciptaan Allah. Misalnya, jika seseorang menanyakan keberadaan Tuhan, maka dengan akalnya ia mampu melihat bagaimana ciptaan Tuhan seperti langit, tumbuhan dan daun yang jatuh dari pohonnya.

\section{Pandangan Sutan Takdir Alisjahbana tentang Tuhan}

Allah yang Maha Kuasa merupakan asal dan pencipta segala sesuatu. Allah menciptakan alam semesta dan mengatur segala sesuatu menurut rancangan dan hukum-Nya. Allah menciptakan matahari dan bumi, mengatur perputaran siang dan malam dan lainnya. Sebagaimana yang diketahui Allah menurunkan hujan yang membasahi tanahm menumbuhkan tumbuhtumbuhan yang akhirnya berbunga dan buahnya dapat dimakan. Allah sebagai pencipta, pemelihara, pelindung, pemimpin, penghibur umatnya dengan penuh kasih sayang (Anna, 2018, h. 136).

Dalam perbuatan, Allah Maha Adil, Maha Pengasih dan Maha Penyayang, tidak ada Tuhan selain Dia (Rusli, 2014, h. 79). Keadilan itu bukan hanya berhubungan dengan kejadian dan perbuatan manusia di dunia tetapi juga berhubungan dengan akhirat kelak. Tuhan memerintahkan manusia untuk selalu menanamkan sifat kasih sayang sehingga selalu sesuatu yang ia lakukan akan mengatasnamakan Allah yang Maha Pengasih dan Maha Penyayang (Anna, 2018, h. 137).

\section{Pandangan Sutan Takdir Alisjahbana tentang akal}

Akal menurut Sutan Takdir Alisjahbana merupakan suatu potensi yang diberikan oleh Allah kepada manusia. Dengan potensi akal ini manusia mampu memilih dan memilah mana yang baik dan yang buruk. Akal menurut STA mampu membedakan mana yang baik dan mana yang buruk namun harus dikonfirmasikan dengan wahyu al-Qur'an dan Sunnah. Akal bagi Sutan Takdir Alisjahbana sangat penting. Akal (rasio) menurutnya mempunyai kedudukan penting dalam kemajuan ilmu, teknologi dan ekonomi (Anna, 2018, h. 111).

Sebagai seorang budayawan, ia sangat terbuka dengan kebudayaan yang datang dari luar. Menurutnya, selagi masih menggunakan akal dengan baik dan tidak keluar dari ajaran Islam maka akan membawa kepada kebaikan. Kebanyakan manusia yang memiliki sikap statis tidak mau melihat kepada dunia luar ia hanya terpaku dengan agama. Di sini terlihat bagaimana pandangan STA. akal menurutnya merupakan informasi sedangkan wahyu yaitu konfirmasi. STA tidak mengatakan bahwa akal lebih tinggi dari wahyu 
namun ia menggunakan akal dan dilihat juga dalam ajaran Islam yaitu alQur'an dan Hadis. Sebagaimana yang diketahui akal menurutnya sebagai informasi dan wahyu sebagai konfirmasi.

\section{Pandangan teologi Sutan Takdir Alisjahbana tentang manusia}

Pandangan Sutan Takdir Alisjahbana terhadap manusia yang terpenting adalah tentang autopoiesis. Autopoiesis merupakan penciptaan atau produksi diri sendiri. Autopoiesis berasal dari kata auto yang berarti diri dan poiesis yang berarti penciptaan atau produksi. Penciptaan disini bermaksud untuk penciptaan atau pelampauan diri entitas yang diterapkan pada skala yang luas. Manusia akan lebih bermakna dan menjadi manusia jika mampu melakukan penciptaan. Artinya manusia yang menghasilkan suatu hal dan dapat dimanfaatkan dalam kehidupannya (Hadi, 2011, h. 18).

Disini terlihat bagaimana pandangan rasional dari Sutan Takdir Alisjahbana. Ia menilai bahwasannya manusia harus mempunyai sikap terbuka dan dinamis serta kreatif. Tidak hanya menerima begitu saja apa yang diberikan tanpa harus berusaha. Menurutnya dengan potensi akal yang diberikan oleh Tuhan, manusia mampu menciptakan suatu perubahan atau kebudayaan baru. Manusia diberi kebebasan oleh Allah selagi tidak keluar dari nilai-nilai agama (Sakina, 2019, h. 1). Dengan dibekali nya manusia berupa potensi akal, maka mereka akan mampu membawa perubahan kepada yang lebih baik. Mampu menciptakan Ilmu pengetahuan dan teknologi serta mampu mempertimbangkan serta menilai mana yang baik dan mana yang buruk (Margono, 2014, h. 73).

\section{Pandangan Sutan Takdir Alisjahbana tentang Balasan di Hari Akhir}

Sebagaimana yang diketahui, manusia telah dianugerahi oleh Allah potensi akal yang dengan itu mereka mampu memilih, memeriksa dan mengambil keputusan ( Nasution, 1995, h. 34). Allah telah memberi kebebasan kepada manusia untuk memilih mana perbuatan yang akan diambil apakah perbuatan buruk atau perbuatan baik yang akan membawa kepada kebaikan. Keadilan Tuhan juga terlihat dalam masalah yang berhubungan dengan pahala di hari akhirat. Dunia sebagaimana yang diketahui adalah jembatan untuk menuju hari akhirat. Allah telah memutuskan bahwa manusia akan mati dan tidak seorangpun akan mati sebelum diizinkan Tuhan. Pada hari pengadilan, orang akan ditimbang kebaikan dan kejahatan yang dilakukan selama hidupnya dan hanyalah yang 
bebas dari api neraka yang akan masuk surga seperti yang akan mencapai tujuan hidupnya (Anna, 2018, h. 137).

Terkait dengan pemikiran liberal dan rasional dari Sutan Takdir Alisjahbana ia lebih memfokuskan kepada kebudayaan Indonesia dan kebudayaan Barat yang ia anggap telah maju dan terbuka. Walaupun ia melihat pemikiran-pemikiran dari Barat namu ia juga masih peduli dengan kebudayaan asli Indonesia yang dianggapnya masih tertutup dengan perkembangan peradaban dunia. Ia melihat antara Barat dan Timur seperti Asia mempunyai penilaian masing-masing dan sebagaimana yang diketahui keduanya sering diidentikkan dengan perlawanan dan permusuhan. Negara Timur menganggap Barat sebagai Negara kapitalis, teknologi, dan imperialisme. Sedangkan kalau orang Barat menilai Negara Timur sebagai Negara yang penduduknya berkembang, miskin, terbelakang dan tradisional. Pemikiran yang seperti ini yang memicu keduanya diidentikkan saling berlawanan dan tidak pernah bersatu. Antara keilmuan umum dan agama saling terkait dan tidak adanya dikotomi (Ismail dkk, 2013, h. 62).

Dalam pandangan Sutan Takdir Alisjahbana, antara Barat dan Timur bisa bersatu dan keduanya saling membutuhkan. Timur yang lebih tradisional harusnya melihat bagaimana perkembangan teknologi di Barat dan menilai proses dari peningkatan tersebut. Sedangkan Barat juga harus melihat bagaimana dunia Timur yang kental dengan nilai-nilai agama, walaupun kaya akan teknologi namun lemah dalam agama itu menjadi sia-sia. Sebaiknya antara ilmu umum dan agama harus sesuai dan selaras. Begitu juga dengan Negara Timur khususnya Negara Indonesia yang masih kental dengan ajaran agamanya harus menyesuaikan antara ilmu agama dan memasukkan ilmu pengetahuan umum. Jika hanya pengetahuan agama, maka selamanya akan tetap jalan ditempat dan tidak akan mampu mengikuti perkembangan dunia luar yang semakin hari semakin maju.

Pemikiran yang seperti ini yang harus ada dalam pandangan orang Indonesia. Menurut Sutan Takdir Alisjahbana, orang Indonesia seharusnya terlepas dari pemikiran yang menilai bahwa pengetahuan yang datang dari Barat itu akan membawa dampak negatif. Sebaliknya harus adanya sikap rasional dan keterbukaan terhadap pengetahuan umum. Selagi mampu memilih dan menyaring ilmu yang masuk maka akan berdampak baik. Mereka menganggap ilmu yang datang dari luar apalagi dari Barat akan membawa kepada kekufuran dan berbeda dengan nilai-nilai yang ada dalam 
agama Islam. Oleh karena itu, mereka tidak mau menerima bahkan menolak apapun yang datang dari Negara Barat seperti Eropa (Yaqin, 2005, h. 5).

Indonesia itu sendiri harus maju dengan cara memperbaiki, mengasah otaknya dan merebut dunia ilmu pengetahuan. Umat Islam di Indonesia tidak boleh ragu dan enggan untuk maju dibanding dunia luar. Kelemahan yang ada di Negara Indonesia menurutnya tidak hanya di bidang ilmu pengetahuan namun juga bidang ekonomi. Kurangnya penggunaan akal (rasio) bagi orang Indonesia dalam bidang ilmu pengetahuan dan ekonomi. Kekurangan inilah yang membuat bangsa Indonesia tertinggal dari Bangsa-Bangsa Barat seperti Eropa. Menurutnya kelemahan ini juga disebabkan karena bangsa Indonesia yang salah dalam menafsirkan tentang agama dan kebudayaan Islam. Dalam ajaran Islam telah ada syarat-syarat untuk memajukan ilmu, ekonomi dan teknologi namun kesalahan penafsiran dari orang Indonesia yang menyebabkan kedudukan mereka rendah dalam kemajuan dunia. Seharusnya mereka mampu bersaing dengan dunia luar jika mereka memanfaatkan potensi akal yang dimiliki.

Dalam pandangan Sutan Takdir Alisjahbana, jika bangsa Indonesia ingin memajukkan perekonomian dan ilmu teknologi yang dapat membawa kepada kebahagiaan dan keselamatan terdapat lima sokoguru yang harus dipakai: (Kohar, 2005, h. 116). Kelima sokoguru yang dimaksud adalah sebagai berikut:

\section{Dasar Tauhid Kepada Allah}

Dasar tauhid ini merupakan modal utama dalam berperilaku. Dengan mengikuti dan patuh akan perintah Sang Pencipta maka akan membawa kepada kebahagiaan dan keselamatan. Seseorang yang sedang mengalami suatu musibah akan lebih mendekatkan diri kepada Sang Kuasa. Misalnya terkena musibah keluarga dekat meninggal. Mereka pasti akan membutuhkan tempat mengadu dan mencari ketenangan. Dengan mendekatkan diri kepada Allah akan membawa kepada ketenangan dan kenyamanan. Sikap ini telah dilakukan oleh Sutan Takdir Alisjahbana seperti ia adalah seorang pribadi yang jujur dan selalu mendekatkan diri kepada Allah.

\section{Dasar Kepedulian Kepada Sesama Manusia}

Kepedulian kepada sesama juga sangat diperlukan. Tidak boleh saling menjatuhkan dan melukai hati orang lain. Harus adanya sikap saling tolong menolong dan saling sayang menyayangi antara sesama makhluk Allah. Sebagaimana yang diketahui, Sutan Takdir merupakan seorang pribadi yang sangat ramah dan selalu berbelas kasih kepada orang lain. Tidak pernah 
membeda-bedakan antara satu dengan yang lain. Sebagai contoh, ia pernah mendirikan yayasan memajukan ilmu dan kebudayaan dengan tujuan agar pemuda tidak ke tangan NICA. Ia juga mengajak para pemuda pada saat itu untuk ikut berpartisipasi dalam masalah politik bahkan filsafat. Oleh karena itu ia tidak hanya sekedar teori saja namun langsung kepada praktek yang jelas (Anna, 2018, h. 113).

\section{Dasar Hakikat Manusia Sebagai Khalifah}

Khalifah berarti wakil Tuhan di muka bumi. Manusia sebagai khalifah di muka bumi maksudnya sebagai wakil Tuhan untuk menegakkan nilai-nilai ajaran Islam dan menyebarkan ajaran Islam kepada semua orang. Manusia dibekali oleh Allah potensi akal yang membedakannya dengan makhluk Tuhan lainnya seperti binatang dan tumbuhan. Dengan begitu, mereka memiliki tanggung jawab yang tinggi akan hal itu. Dengan begitu besar pengaruh dari Sutan Takdir Alisjahbana dalam bidang politik, sastra di Indonesia bahkan ia juga pernah menyadarkan para narapidana saat ia dipenjara merupakan suatu bentuk tanggung jawab yang telah dilakukan seorang khalifah di muka bumi. Selain itu ia juga pernah memperjuangkan rakyat khususnya di Sumatera yaitu dengan mendirikan Jong Sumatera.

\section{Ilmu Pengetahuan}

Ilmu pengetahuan sangat penting dalam kehidupan manusia. Dengan berilmu maka mereka akan dapat mengikuti perkembangan zaman yang semakin hari semakin canggih dan maju. Jika ia berilmu pengetahuan dan memanfaatkan potensi akan yang diberikan oleh Allah maka mereka akan menjadi Khalifah Allah yang sejatinya di muka bumi. Ia akan menjadi penebar kebaikan dan menyebarkan ajaran Islam. Selain itu, dengan ilmu pengetahuan yang ia dapatkan akan membawa kepada ketakwaan kepada Yang Esa. Karena mereka akan memiliki pandangan bahwa hanya kepada Tuhan Esalah tempat mengadu setiap permasalahan dan tidak ada selainNya. Mereka yang mengantungkan diri kepada berhala dikarenakan kurang ilmu pengetahuan dan penggunaan potensi akal dari Tuhan (Anna, 2018, h. 115).

\section{Dasar Ekonomi Sejahtera}

Ekonomi juga menjadi pokok utama dalam meningkatkan kesejahteraan dalam suatu negara. Perekonomian yang baik dan maju akan meningkatkan mutu pendidikan dan kemakmuran bagi masyarakat dalam suatu negara. Dengan ekonomi yang baik akan mendorong ilmu pengetahuan 
serta ketiga aspek di atas seperti tauhid kepada Allah, rasa solidaritas dan sebagai khalifah. Jika seseorang mempunyai kelebihan dalam masalah ekonomi maka akan mendorong terciptanya rasa saling membantu kepada yang membutuhkan, akan menunaikan ibadah haji dan juga mendorong pendidikan ke jenjang yang lebih tinggi. Itu dapat dilihat dari peristiwa seseorang yang apabila ia memiliki harta yang berlebih maka ia akan dengan semangat menyekolahkan anaknya sampai kemanapun. Dan kejadian ini akan mendorong meningkatnya mutu pendidikan dan tidak terbelakangnya pendidikan di Indonesia (Kohar, 2005, h. 119).

Kelima sokoguru ini apabila dilakukan serta dipraktekan dengan baik di Indonesia menurut Sutan Takdir Alisjahbana, maka akan membawa dampak serta perubahan yang lebih baik kepada Indonesia untuk masa depan. Indonesia tidak lagi terbelakang baik di bidang ilmu pengetahuan, ekonomi dan teknologi. Indonesia akan mampu bersaing dengan dunia luar dan akan diakui kecanggihan dan ilmu pengetahuan. Oleh karena itu antara agama dan ilmu pengetahuan umum harusnya seimbang dan tidak berdikotomi. Harus adanya integrasi dan interkoneksi antara kedua keilmuan ini. Antara satu dengan yang lain saling membutuhkan dan tidak bisa terpisahkan.

\section{Implikasi Teologi Islam Rasional Sutan Takdir Alisjahbana di Era Modern}

Sekarang ini, dapat dilihat kebanyakan manusia hanya pasrah dan tunduk akan semua kehendak dan takdir Allah. Padahal Allah telah menganugerahi potensi akal kepada manusia yang dengan itu manusia mampu untuk memilih dan memilah mana yang baik dan mana yang tidak baik atau dengan kata lain yang tidak sesuai dengan ajaran Islam. Dengan teologi Islam rasional dari Sutan Takdir Alisjahbana ini maka mampu mengantarkan atau menuntun manusia kepada kemajuan serta mampu mengikuti perkembangan zaman.

Perkembangan ilmu pengetahuan dan kecanggihan teknologi sekarang ini menuntut manusia untuk selalu berpikiran terbuka dan mau menerima kemajuan dari negara lain yang notabene telah maju dari negara Indonesia. Disinilah letak implikasi dari teologi rasional Sutan Takdir Alisjahbana. Pandangannya tentang kedudukan akal dalam kehidupan manusia mampu menunjukkan bagaimana akal mampu membawa manusia menuju peradaban modern dan tidak tertinggal dari negara-negara lain asalkan sesuai dengan negara Indonesia itu sendiri. Manusia yang bersifat statis dan tidak mau berubah serta terbuka akan membawa kepada kemunduran baik ilmu 
pengetahuan, ekonomi maupun teknologi. Kemajuan ilmu pengetahuan dan teknologi yang semakin hari semakin meningkat ini akan mampu dilalui jika manusia menggunakan potensi akal yang dimiliki namun tidak boleh bertentangan dengan ajaran Islam yaitu al-Qur'an dan Sunnah.

Dalam hal ini, pemikiran teologi Islam rasional Sutan Takdir Alisjahbana akan selalu selaras dengan kemajuan ilmu pengetahuan dan peradaban manusia. Bagi mereka yang mampu menggunakan potensi akalnya dengan baik dan tidak bertentangan dengan ajaran Islam al-Qur'an dan Sunnah maka mereka tidak akan mengalami kemunduran dan akan selalu mengikuti perkembangan yang semakin hari semakin meningkat. Berbeda dengan mereka yang hanya pasrah dan tidak mau tau dengan perkembangan yang ada. Mereka akan tertinggal dan jalan di tempat.

\section{PENUTUP}

Dari pemaparan terkait teologi Islam dan rasional Sutan Takdir Alisjahbana di atas nampaklah beliau adalah seorang tokoh liberal dan rasional Indonesia. Seorang tokoh budayawan, sastrawan dan ahli bahasa Indonesia yang berasal dari Natal, Tapanuli Selatan tepatnya di pantai Barat Sumatera pada 11 Februari 1908. Ia berasal dari keturunan Minangkabau dari pihak ibu dan dari keturunan ayah berdarah Jawa. Sutan Takdir Alisjahbana ini sangat memperhatikan kebudayaan yang ada di Indonesia dan terhadap semua pembaharuan yang ada di Indonesia.

Sutan Takdir Alisjahbana menilai bahwa kebudayaan Indonesia masih bersifat statis dan terbelakang. Mereka hanya tunduk kepada mitos-mitos dan ilmu gaib yang ada tanpa mau melihat kepada dunia luar. Paradigm masyarakat Indonesia terhadap dunia Barat masih sama dengan dahulu yaitu menganggap bahwa ilmu pengetahuan yang datang dari Barat akan membawa kepada kekufuran dan sangat berbeda dengan nilai-nilai yang ada dalam agama Islam. Namun, menurut Sutan Takdir Alisjahbana tidaklah demikian. Justru dengan adanya sifat terbuka kepada dunia Barat dan mampu menggunakan akal untuk memilih dan memilah akan membawa kepada kemajuan dalam dunia Islam khususnya di Indonesia.

Terkait teologinya, Sutan Takdir Alisjahbana tidak menolak ajaran Islam sama sekali. Ia menyeimbangkan antara akal dan wahyu dalam memahami ajaran Islam seperti akal dan wahyu. Misalnya dalam melihat kemajuan dunia, ia menerima semua teknologi dan ilmu pengetahuan yang datang dari Barat namun ia memilih dan memilah mana pemikiran yang sesuai dengan ajaran Islam. Jika menurut ajaran Islam tidak sesuai maka akan 
ditolak dan ditentang. Semua yang masuk ke dalam kebudayaan Indonesia harus diseimbangi dan disesuaikan dengan ajaran Islam Al-Quran dan Sunnah. Dalam menanggapi hal di atas beliau mengemukakan bahwa untuk memajukan dan mensejaterakan serta agar Indonesia mampu bersaing dengan dunia Barat maka diperlukan lima sokoguru, yaitu: dasar ketauhidan kepada Tuhan, dasar solidaritas kepada sesama, dasar kekhalifahan, dasar ilmu pengetahuan dan dasar ekonomi.

\section{DAFTAR REFERENSI}

Abdul Kohar. 2021. Islamic Theology And Rasionalism: Analisis Pemikiran Sutan Takdir Alisjahbana." Pemikiran Keislaman, Vol.31.

Ainul Yaqin. 2005. Studi Kritis Terhadap Pemikiran Kebudayaan Sutan Takdir Alisjahbana. Yogyakarta: UIN Sunan Kalijaga.

Abdullah, Amin. 2007. Islamic Studies: Paradigma Integrasi-Interkoneksi Sebuah Antologi. Yogyakarta: SUKA Press.

Anna, Dian Nur. 2018. Seni Dan Agama Dalam Islam Menurut Sutan Takdir Alisjabbana. Yogyakarta: Bildung.

Hartono Margono. 2014. Human Reality and Perfection in The Philosophical View of Sutan Takdir Alisjahbana. Miqot, Vol. XXXVIII.

Nasution, Harun. 1986. Teologi Rasional: Aliran-Aliran Sejarab Analisa Perbandingan. Jakarta: UI Press.

. 1995. Islam Rasional: Gagasan Dan Pemikiran. Bandung: Mizan.

Bagus, Lorens. 1996. Kamus Filsafat. Jakarta: PT Gramedia Pustaka Media.

Mangunhardjana. 1997. Isme-Isme Dalam Etika: Dari A Sampai Z. Yogyakarta: Kanisius.

Mansur, Laily. 1994. Pemikiran Kalam Dalam Islam. Jakarta: Pustaka Firdaus.

Rusli, Ris'an. 2014. Teologi Islam: Telaah Sejarah Dan Pemikiran Tokoh-Tokohnya. Jakarta: Prenadamedia Group.

Ismail, Roni dkk. 2013. Integrasi-Interkoneksi Keilmuan UIN Sunan Kalijaga: Sebuah Interpretasi Dan Aplikasi. Yogyakarta: Bagian Akademik UIN Sunan Kalijaga.

Alisjahbana, S. Takdir. 1977. Perkembangan Sejarah Kebudayaan Indonesia: Dilibat Dari Jurusan Nilai. Jakarta: Idayu Press.

1992. Pemikiran Islam Dalam Menghadapi Globalisasi Dan Masa Depan Umat Manusia. Jakarta: Dian Rakyat.

Sakina. 2019. Konsep Manusia Dalam Pemikiran Sutan Takdir Alisjahbana. 
Jambi: UIN Sulthan Thaha Saifuddin.

Sumasno Hadi. 2011. Pemikiran Sutan Takdir Alisjahbana.” Filsafat, Vol. 21.

Suseno, Frans Magnis. 1998. Tiga Model Pendekatan Etika. Yogyakarta: Kanisius. 